\title{
Clinical significance of anti-cyclic citrullinated peptide antibodies in Egyptian patients with chronic hepatitis $\mathrm{C}$ virus genotype IV infection
}

\author{
Iman H. Bassyouni ${ }^{1}$, Yasser Ezzat ${ }^{2}$, Sherif \\ Hamdy $^{3}$ and Roba M. Talaat ${ }^{4, *}$ \\ ${ }^{1}$ Department of Rheumatology and Rehabilitation, \\ Faculty of Medicine, Cairo University, Egypt \\ ${ }^{2}$ Department of Rheumatology and Rehabilitation, \\ Faculty of Medicine, Fayoum University, Egypt \\ ${ }^{3}$ Department of Tropical Medicine, Faculty of \\ Medicine, Cairo University, Egypt \\ ${ }^{4}$ Department of Molecular Biology, Genetic \\ Engineering and Biotechnology Research Institute \\ (GEBRI), Minofia University, Egypt
}

\begin{abstract}
Background: Symmetric polyarthritis associated with hepatitis $\mathrm{C}$ virus (HCV) infection frequently displays a clinical picture like rheumatoid arthritis (RA). Antibodies to cyclic citrullinated peptide (CCP) have high specificity for the diagnosis of RA. This study examined the frequency and clinical significance of antiCCP antibodies in patients with chronic HCV infection, with and without manifestations of joint involvement, compared to RA patients.

Methods: Serum anti-CCP antibodies and rheumatoid factor (RF) were evaluated in 30 patients with RA and 47 patients with chronic HCV infection. Of those with $\mathrm{HCV}$ infection, 20 patients had chronic HCV infection associated with articular involvement and 27 patients had chronic HCV infection without any articular involvement.

Results: Anti-CCP antibody level was positive in $70 \%$ of RA patients, $8.5 \%$ of HCV-infected patients, and in $20 \%$ of HCV patients with articular manifestations. RF was positive in $76 \%$ of RA patients and in $60 \%$ of HCV patients with articular involvement. Cryoglobulins were found in $29 \%$ of HCV-infected patients and in $16 \%$ of RA patients. Cryoglobulins were more frequent among HCV patients with articular affection (35\%) compared to HCV patients without articular affection (26\%).

Conclusions: Although anti-CCP antibodies remain a useful diagnostic tool for RA, their interpretation in HCV-infected patients with arthritis should be applied with caution. The possibility that those patients could be prone to develop RA cannot be ruled out. Those patients need careful clinical and radiological followup. Further large-scale studies are warranted. Clin Chem Lab Med 2009;47:842-7.
\end{abstract}

*Corresponding author: Dr. Roba M. Talaat, Department of Molecular Biology, Genetic Engineering and Biotechnology Research Institute (GEBRI), Minofiya University, Egypt

Phone: +2 048260 1264/65, + 2012327 4535, Fax: + 2048

260 1266/68, E-mail: Robamtalaat@yahoo.com

Received January 18, 2009; accepted April 13, 2009
Keywords: anti-cyclic citrullinated peptide (anti-CCP); cryoglobulins; hepatitis C virus (HCV); rheumatoid arthritis (RA); rheumatoid factor (RF).

\section{Introduction}

Infection with hepatitis C virus (HCV) remains a severe life-threatening medical and public health problem worldwide (1). The highest prevalence has been reported from Egypt (2) where the main HCV genotype is type IV, representing $90 \%$ of the Egyptian HCV-infected population (3). It has emerged as a major cause not only of liver disease, but also of numerous extrahepatic conditions (4). Many rheumatologic manifestations were associated with HCV infection, some of which are related to mixed cryoglobulinemia, whose link to the HCV is now firmly established (5).

Among the different clinical disorders associated with HCV infection, articular involvement is a frequent complication. HCV arthropathy frequently displays a rheumatoid arthritis (RA)-like clinical picture, and most patients with RA-like HCV related polyarthritis fulfill the American College of Rheumatology (ACR) criteria for RA (6). However, compared to RA, HCVassociated arthritis is usually less severe and does not cause joint deformities or rheumatoid nodules (7). Because the classic clinical picture of RA is not entirely helpful in the differential diagnosis, other diagnostic tools such as the detection of serological abnormalities in sera of patients with RA, could be helpful in differentiating between these disorders (8).

The detection of classic immunoglobulin $\mathrm{M}$ ( $(\mathrm{gM})$ rheumatoid factor (RF) is of little utility as a diagnostic tool for RA because a high percentage of patients with chronic HCV infection display serum RF reactivity. Also, the frequency of RF increases in patients with articular involvement (9). During the last few years, a variety of circulating non-RF antibodies have been discovered and reported to have a potential diagnostic value $(10,11)$. Anti-cyclic citrullinated peptide (antiCCP) antibodies are antibodies against synthetic citrullinated peptides, and are specific markers of RA (12). Anti-CCP antibodies are disease-specific and sensitive markers for RA. In addition to their diagnostic properties, anti-CCP antibodies have also been shown to be good prognostic markers, as they help predict the erosive or non-erosive progression of the disease and anti-CCP antibodies are usually present early in the course of disease (10). The present study aimed to examine the frequency and clinical significance of anti-CCP antibody in patients with chronic 
HCV infection, with and without manifestations of joint involvement, compared to patients with RA.

\section{Materials and methods}

\section{Patients}

All patients enrolled in this study were referred to the Rheumatology and Rehabilitation Department and Tropical Medicine Department of El-Kasr El-Aini Hospital, Cairo University, Egypt, from January 2006 to December 2007. All investigations were done in accordance with the Cairo University, health and human Ethical Clearance Committee guidelines for clinical researches. The local Ethics Committee approved the study protocol. All patients agreed to be enrolled in this study.

All participants underwent a general and locomotor clinical examination and gave a detailed history. Demographic, clinical, immunochemical, virological, and liver histology features were collected retrospectively for each patient. HCV antibodies were measured using a 3rd generation enzyme linked immunosorbent assay (ELISA) (Murex Biotech, Dartford, UK) and confirmed using reverse transcriptase polymerase chain reaction (RT-PCR) (Promega Co., Madison, WI, USA). Hepatitis B surface antigens (HBsAg) (Sorin Biomedica Co., Saluggia, Italy) were measured using commercially available kits. All patient groups were positive for HCV antibody and HCV-RNA.

Forty-seven HCV infected patients were enrolled. Two groups of HCV patients were identified on the basis of the presence of HCV-related arthropathy; Group I (20 patients with articular involvement) and Group II (27 patients without articular involvement). Patients with evidence of deformity, erosions on radiographs or subcutaneous nodules were excluded from the study. The control group for the diagnostic reliability of the anti-CCP antibody was comprised of 30 patients with a definitive diagnosis of RA as per ACR criteria (6). Controls were sero-negative for HCV.

\section{Anti-CCP antibodies}

Anti-CCP antibodies were measured using a commercial anti-CCP ELISA kit (EUROIMMUN Medizinische Labordiagnostika AG, Lübeck, Germany) according to the manufacturer's instructions. A cut-off value of five relative units was established, as recommended by the manufacturer's protocol. The cut-off value was established by evaluating 419 patients with RA, 744 patients without RA and 400 healthy controls. Values $>5$ units were considered positive for antiCCP immunoglobulin $\mathrm{G}(\mathrm{IgG})$ antibodies. We considered the validation studies performed by the manufacturer to be sufficient and to preclude the need for use of a healthy control population in our study.

\section{Rheumatoid factor (RF)}

RF was determined using a latex fixation method. A suspension of uniform polystyrene particles sensitized in glycine buffer with heat-altered human IgG (BD Diagnostic Systems, Sparks, MD, USA) was incubated with progressive dilutions of human sera in microtitre wells. After incubation, the plates were visually inspected for agglutination.

\section{Cryoglobulin detection}

Venous blood was collected in a pre-warmed syringe and stored at $37^{\circ} \mathrm{C}$ until clotted. Serum was centrifuged at $37^{\circ} \mathrm{C}$ for $10 \mathrm{~min}$ at $2500 \mathrm{rpm}$ (559 g), collected and stored at $4^{\circ} \mathrm{C}$ for 7 days. After isolation and washing, the components of the cryoprecipitate were characterized by immunofixation (13).

\section{Radiographic assessment}

Plain X-rays for both hands and wrists were obtained on chronic HCV patients who had articular involvement at the time of anti-CCP antibody analysis. If erosions were present, the diagnosis of HCV related arthropathy was discarded, and the patients were now considered to have RA with concomitant HCV infection. The radiographs of all patients were reviewed by a senior rheumatologist.

\section{Liver biopsy}

Liver biopsy was performed whenever possible and assessed histopathologically (14).

\section{Statistical analysis}

The Statistical Package for Social Sciences (SPSS) version 10 (LEAD Technology Inc., Charlotte, NC, USA) was used to analyze patient data. Descriptive statistics included the mean and standard deviation (SD) for quantitative variables, and number and percentage for qualitative variables. Unpaired t-test and Chi-square $\left(\chi^{2}\right)$, with Fisher exact test when appropriate, were used for statistical comparative analysis. A difference was considered to be statistically significant when the $(p)$ value was $\leq 0.05$.

\section{Results}

\section{Clinical and demographic data of studied population}

We enrolled $47 \mathrm{HCV}$-infected patients, ranging from 20 to 57 years of age, and 28 being female. All had HCV genotype IV. Table 1 summarizes the demographic, clinical and serological characteristics of the HCV-infected patients, with and without articular involvement. Comparing HCV patients with articular involvement to those without articular involvement, no statistically significant differences were found between any of the variables mentioned in the table. Histological examination of hepatic biopsies showed grading of activity from minimum to severe, with no significant difference between patients with and without arthritis.

Table 2 shows the demographic, articular characteristics and erythrocyte sedimentation rate (ESR) levels of patients with RA, and of HCV patients with articular involvement. With respect to the pattern of articular involvement in HCV patients with articular involvement, all of them complained of polyarthralgias (20/20), three had mono-pauciarticular involvement of large joints with predominance of the knee, and nine had RA-like polyarthritis of the diarthroidal joints of the hands.

\section{Mean anti-CCP antibodies level in patients studied}

The mean for anti-CCP antibodies was $3.00 \pm 5.64$ $\mathrm{U} / \mathrm{mL}$ (range $0.32-32.62$ ) in the HCV group, while it was $19.84 \pm 19.45 \mathrm{U} / \mathrm{mL}$ (range 1.3-75) in the RA 
Table 1 Clinical, demographic and laboratory characteristics of HCV patients with and without articular involvement.

\begin{tabular}{|c|c|c|c|}
\hline Variable & $\begin{array}{l}\text { HCV with articular } \\
\text { involvement } \\
n=20\end{array}$ & $\begin{array}{l}\text { HCV without } \\
\text { articular involvement } \\
n=27\end{array}$ & $p$-Value \\
\hline Age, years ${ }^{a}$ & $34.10 \pm 10.10$ & $38.27 \pm 10.86$ & NS \\
\hline Female/male & $12 / 8$ & $16 / 11$ & NS \\
\hline Sicca syndrome & $6(30)$ & $4(14)$ & NS \\
\hline Parathesia ${ }^{\mathrm{b}}$ & $5(25)$ & $6(22)$ & NS \\
\hline Myalgias $^{b}$ & $7(35)$ & $8(29)$ & NS \\
\hline Vasculitis $^{b}$ & $7(35)$ & $5(18.5)$ & NS \\
\hline Raynauds ${ }^{b}$ & $4(20)$ & $4(14.8)$ & NS \\
\hline $\mathrm{ESR}, \mathrm{mm} / 1 \mathrm{st} \mathrm{h}^{\mathrm{a}}$ & $35.4 \pm 13.7$ & $29.32 \pm 10.12$ & NS \\
\hline $\mathrm{AST}, \mathrm{U} / \mathrm{L}^{\mathrm{a}}$ & $51.64 \pm 10.20$ & $56.6 \pm 12.70$ & NS \\
\hline $\mathrm{ALT}, \mathrm{U} / \mathrm{L}^{\mathrm{a}}$ & $51.09 \pm 13.60$ & $45.8 \pm 19.50$ & NS \\
\hline Serum albumin ${ }^{a}$ & $3.82 \pm 0.47$ & $3.54 \pm 1.92$ & NS \\
\hline Creatinine, $\mu \mathrm{mol} / \mathrm{L}^{\mathrm{a}}$ & $65.416 \pm 10.608$ & $60.996 \pm 15.912$ & NS \\
\hline Hemoglobin, g/ $\mathrm{L}^{\mathrm{a}}$ & $127 \pm 11.3$ & $132 \pm 15.2$ & NS \\
\hline WBCs, $\times 10^{9} / \mathrm{L}^{\mathrm{a}}$ & $5.60 \pm 1.81$ & $4.8 \pm 1.42$ & NS \\
\hline $\mathrm{PLT}, \times 10^{9} / \mathrm{L}^{\mathrm{a}}$ & $271.09 \pm 88.08$ & $233.4 \pm 75.6$ & NS \\
\hline
\end{tabular}

alues are mean $\pm \mathrm{SD}$; 'balues are $\mathrm{n}(\%)$; HCV, hepatitis $\mathrm{C}$ virus; ESR, erythrocyte sedimentation rate; AST, aspartate transaminase; ALT, alanine transaminase; WBCs, white blood cells; PLT, platelets; NS, not significant.

Table 2 Demographic, articular characteristics and ESR levels of patients with RA and HCV patients with articular involvement.

\begin{tabular}{|c|c|c|}
\hline Variable & $\begin{array}{l}\text { RA patients } \\
n=30\end{array}$ & $\begin{array}{l}\mathrm{HCV} \text { with articular } \\
\text { involvement } \\
\mathrm{n}=20\end{array}$ \\
\hline Age, years ${ }^{a}$ & $39.2 \pm 10.6$ & $34.10 \pm 10.10$ \\
\hline $\begin{array}{l}\text { Duration of articular } \\
\text { manifestations, years }\end{array}$ & $6.5 \pm 4.9$ & $2.89 \pm 1.73$ \\
\hline Morning stiffness $>1 \mathrm{~h}^{\mathrm{b}}$ & $22(73)$ & $9(45)$ \\
\hline $\begin{array}{l}\text { Arthritis of } 3 \text { or more } \\
\text { joint areas }{ }^{b}\end{array}$ & $28(93.3)$ & $9(45)$ \\
\hline Symmetric arthritis ${ }^{\mathrm{b}}$ & $28(93.3)$ & $7(35)$ \\
\hline Subcutaneous nodules ${ }^{\mathrm{b}}$ & $3(10)$ & 0 \\
\hline Deformity ${ }^{b}$ & $14(46)$ & 0 \\
\hline Radiological erosions ${ }^{b}$ & $11(36)$ & 0 \\
\hline $\mathrm{ESR}, \mathrm{mm} / 1 \mathrm{st} \mathrm{h}^{\mathrm{a}}$ & $42 \pm 24$ & $35.4 \pm 13.7$ \\
\hline
\end{tabular}

avalues are mean \pm SD; ${ }^{b}$ values are $n(\%)$; ESR, erythrocyte sedimentation rate; RA, rheumatoid arthritis; $\mathrm{HCV}$, hepatitis $\mathrm{C}$ virus.

group $(\mathrm{p}<0.001)$. Mean levels were highly significant $(p<0.001)$ when comparing the RA group to the HCV patients with arthritis $(5.22 \pm 8.13 \mathrm{U} / \mathrm{mL})$. In addition, a significant difference $(p<0.05)$ was found when comparing mean anti-CCP antibodies in patients with $\mathrm{HCV}$ and articular involvement to those without articular involvement $(1.36 \pm 1.18 \mathrm{U} / \mathrm{mL})$. Figure 1 shows the anti-CCP antibody levels for the various disease categories.

\section{Prevalence of anti-CCP antibodies, RF, and cryoglobulins in studied patients}

Anti-CCP antibodies were positive in only four patients, representing $8.5 \%$ of the HCV-infected group. Three patients tested positive for both antiCCP antibodies and RF, and had symmetric polyarthritis (RA-like). Their ages ranged from 36 to 52 years and their duration of disease (with respect to arthritis) ranged from 4 to 6 years. Table 3 summarizes the characteristics of HCV patients with elevated anti-CCP antibody levels.
The prevalence of anti-CCP antibody positive patients increased to $20 \%(4 / 20)$ in patients having chronic HCV and articular involvement, while the prevalence was zero in chronic HCV patients without articular involvement. This finding was statistically significant $(p<0.05)$. Anti-CCP antibody level was positive in $70 \%$ of the RA patients. A significant difference $(p<0.001)$ was found between the frequency of antiCCP antibodies between the RA group and chronic HCV patients with arthritis. RF was positive in $76 \%$ of RA patients, whereas it was found in $60 \%$ of patients affected by HCV with articular involvement (12/20); this difference was statistically insignificant. However, a statistically significant difference $(p<0.05)$ was

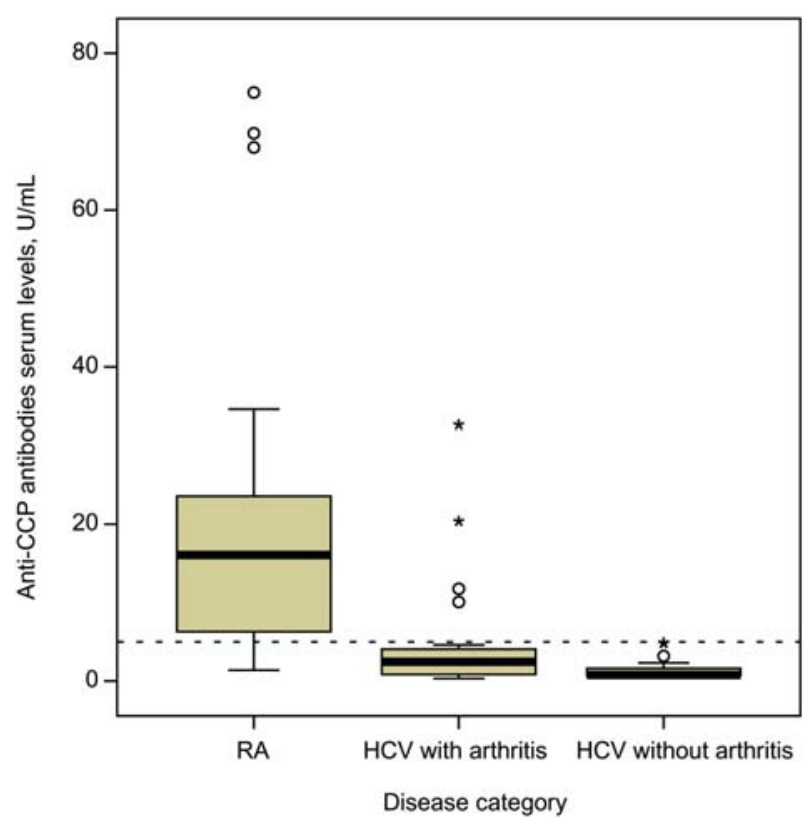

Figure 1 Serum anti-CCP antibody levels in the various disease categories.

Data are presented as box plots with lines inside the box representing medians, boxes representing the 25th and 75th percentiles and the lines outside the boxes indicating the 10 th and 90th percentiles. 
Table 3 Characteristic of HCV patients with elevated anti-CCP antibody levels.

\begin{tabular}{lllll}
\hline Patient no. & 2 & 7 & 8 & 14 \\
\hline Age, years & 36 & 43 & 52 & 43 \\
Sex & $\mathrm{M}$ & $\mathrm{F}$ & $\mathrm{F}$ & $\mathrm{F}$ \\
Arthralgia & $\mathrm{Y}$ & $\mathrm{Y}$ & $\mathrm{Y}$ & $\mathrm{Y}$ \\
Duration of arthritis, years & 4 & 6 & 4 & 4 \\
RA like arthritis & $\mathrm{Y}$ & $\mathrm{N}$ & $\mathrm{Y}$ \\
Pauciarticular arthritis & $\mathrm{N}$ & $\mathrm{Y}$ & $\mathrm{N}$ \\
Sicca syndrome & $\mathrm{N}$ & $\mathrm{Y}$ & $\mathrm{Y}$ \\
Parathesia & $\mathrm{N}$ & $\mathrm{N}$ & $\mathrm{N}$ \\
Myalgia & $\mathrm{Y}$ & $\mathrm{N}$ & $\mathrm{N}$ \\
Vasculitis & $\mathrm{Y}$ & $\mathrm{N}$ & $\mathrm{Y}$ \\
Raynauds phenomenon & $\mathrm{Y}$ & $\mathrm{N}$ & $\mathrm{N}$ \\
ALT, U/L & 52 & $\mathrm{Y}$ & 79 & 46 \\
AST, U/L & 45 & 34 & 54 & 59 \\
ESR, mm/1st h & 20 & 61 & 35 & 52 \\
RF & $\mathrm{Y}$ & 48 & $\mathrm{~N}$ & $\mathrm{~N}$ \\
Cryoglobulin & $\mathrm{N}$ & $\mathrm{N}$ & $\mathrm{Y}$ \\
Anti-CCP antibodies & 10.09 & $\mathrm{Y}$ & 32.62 & 20.30 \\
\hline
\end{tabular}

$\mathrm{Y}$, yes; N, no; M, male; $\mathrm{F}$, female; ALT, alanine transaminase; AST, aspartate transaminase; ESR, erythrocyte sedimentation rate; $\mathrm{RF}$, rheumatoid factor; anti-CCP, anti-cyclic citrullinated peptides.

found when comparing the frequency of RF in HCV patients with arthritis to those without arthritis. Cryoglobulins were found in 14 of the chronic HCVinfected patients $(29 \%)$, and in five patients with RA $(16 \%)$. Although cryoglobulins were more frequent among chronic HCV patients with articular affection $(35 \%)$ compared to those without affection (26\%), the difference was not statistically significant. Figure 2 shows the prevalence of anti-CCP antibodies, RF and cryoglobulins in RA and HCV-infected patients.

\section{Discussion}

The articular manifestations of chronic HCV and RA may be very similar, and the prevalence of RF is the same in the two conditions (15). Numerous studies have corroborated the high specificity ( $>95 \%$ ) of the anti-CCP assay for the diagnosis of RA, and its association with erosive inflammatory joint disease has added to the prognostic value of anti-CCP antibodies (10). However, the control sera used to assess the specificity of this assay were derived primarily from normal subjects and patients with a wide variety of rheumatic diseases; patients with HCV were not wellrepresented (10). Thus, the objective of our study was to assess the presence of anti-CCP antibodies in patients with HCV infection, with and without manifestations of joint involvement, in comparison to patients with RA.

Van Boekel et al. (16) concluded that anti-CCP antibodies had the most value for diagnosis of RA. Despite the high specificity described for the anti-CCP antibody test, four (i.e., 8.5\%) patients from the HCV-

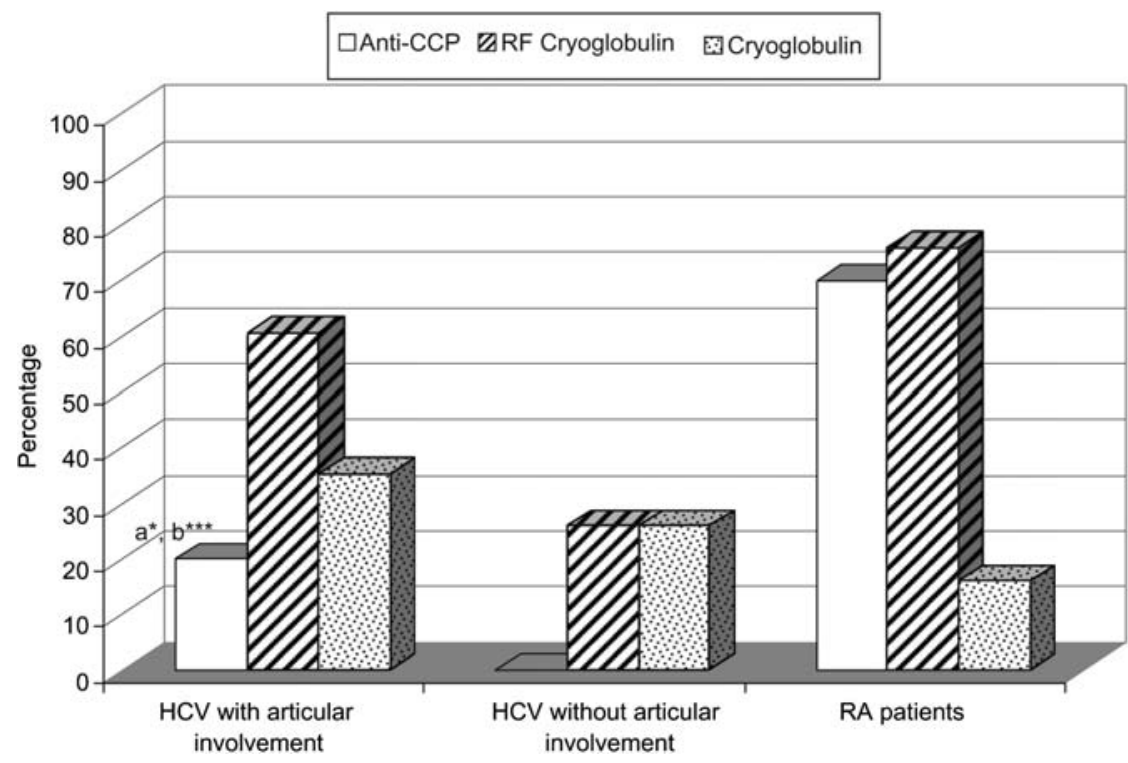

Figure 2 Prevalence of anti-CCP antibody, RF and cryoglobulins in RA and HCV-infected patients.

(a) Statistically significant from HCV patients without articular involvement. (b) Statistically significant from RA patients. ${ }^{*} p<0.05 ;{ }^{* *} p<0.001$. 
infected group were positive for anti-CCP antibodies. The prevalence increased to $20 \%(4 / 20)$ when considering only HCV with articular manifestations, while anti-CCP antibodies were absent in patients without articular involvement. On the other hand, the frequency of cryoglobulins and RF was comparable between $\mathrm{HCV}$ patients and RA patients in our patient cohort. The previously reported prevalence of anti-CCP antibodies among patients with HCV ranged from none to $9 \%$, depending on the population studied and whether it was associated with cryoglobinemia (17-20). For example, Sène et al. (17) found anti-CCP antibodies positive in $5.7 \%$ of HCV-infected patients with arthralgia, whereas they were present in $78 \%$ of patients with RA. Another study detected anti-CCP antibodies in $6.9 \%$ of patients with mixed cryoglobulins (18). Similarly, Liu et al. (19) detected a significant number of HCV-infected patients with RF and cryoglobulinemia who were also positive for anti-CCP antibodies. On the other hand, Girelli and colleagues (20) reported that RF was present in $91 \%$ of patients with RA and $86 \%$ of the patients who had HCV-related arthritis, whereas anti-CCP antibodies were seen in $71 \%$ and $0 \%$ of patients, respectively.

Although our study reconfirms the association of anti-CCP antibodies with RA (present in $70 \%$ ), the number of our patients with HCV arthritis who have anti-CCP antibodies is greater than would be expected with respect to the high specificity of the test (16). The high prevalence of anti-CCP antibodies might reflect ethnic differences or different genotypes of the HCV virus (i.e., IV) found in our patients, which differ compared to patients evaluated in other studies. It has been suggested that chronic HCV with genotypes IV through IX may exhibit epidemiologic, clinical, and treatment outcomes different from those for genotypes I, II, or III (21).

The synthesis of citrullinated proteins has been shown to increase as a result of both apoptosis and inflammation-induced cellular death (necroinflammation). This suggests that this process is inflammationdependent rather than disease-dependent $(22,23)$. Moreover, the presence of anti-CCP antibody has been reported, in low prevalence, in association with systemic lupus erythematosus, systemic sclerosis, polymyositis (24), Sjögren syndrome (25) and psoriasis $(26,27)$. Recently, a relatively high percentage $(9 \%)$ of patients with anti-CCP antibody was detected in a large group of individuals with autoimmune hepatitis, but without apparent overlap with RA (28).

The basis for the association of anti-CCP antibodies with HCV arthritis in our study of patients with chronic $\mathrm{HCV}$ is speculative. It might be a part of the heightened immune reactive state characteristic of $\mathrm{HCV}$ infection, in which epitope spread and molecular mimicry result in multiple serological reactivities, or concurrent immune disorders with the production of a wide range of autoantibodies produced against liver- and non-liver-specific autoantigens (29-31).

Extravascular citrullinated fibrin is one of the citrullinated proteins that trigger production of anti-CCP antibodies in patients with RA. HCV infection can cause chronic liver injury with the release of large amounts of fibrin and fibrin fragments that can be citrullinated. These citrullinated antigens may then activate CD4 + T helper cells and stimulate production of anti-CCP (30). The presence of mRNA of peptidylarginine deiminase (PAD) enzyme in fetal liver, with the occurrence of citrullination processes within this organ, and subsequent release of liver-derived substrates could lead to the generation anti-CCP antibodies (32).

To summarize, our results suggest that anti-CCP antibodies may be present in HCV patients presenting with articular manifestations, but must be interpreted with caution. However, it is possible that patients with anti-CCP antibody could be prone to develop RA. It is well known that anti-CCP antibodies can be present years before the first sign of RA. Careful clinical and radiological follow-up is required to confirm the absence of evolution to RA in anti-CCP antibody positive patients. Further large-scale studies are warranted.

\section{References}

1. Global burden of disease (GBD) for hepatitis C. J Clin Pharmacol 2004;44:20-9.

2. Perz J, Armstrong G, Farrington L, Hutin $Y$, Bell B. The contributions of hepatitis $B$ virus and hepatitis $C$ virus infections to cirrhosis and primary liver cancer worldwide. J Hepatol 2006;45:529-38.

3. Chamberlain R, Adams N, Saeed A, Simmonds P, Elliott R. Complete nucleotide sequence of a type 4 hepatitis $C$ virus variant, the predominant genotype in the Middle East. J Gen Virol 1997;78:1341-7.

4. WHO. Global surveillance and control of hepatitis C. J Viral Hepat 1999;6:35-47.

5. Lormeau C, Falgarone G, Roulot D, Boissier M. Rheumatologic manifestations of chronic hepatitis $C$ infection. Joint Bone Spine 2006;73:633-8.

6. Arnett F, Edworthy S, Bloch D, McShane D, Fries J, Cooper N. The American Rheumatism Association 1987 revised criteria for the classification of rheumatoid arthritis. Arthritis Rheum 1988;31:315-24.

7. Ramos-Casals M, Jara L, Medina F, Rosas J, Calvo-Alen $\mathrm{J}$, Mana $\mathrm{J}$, et al. Systemic autoimmune diseases coexisting with chronic hepatitis $\mathrm{C}$ virus infection (the HISPAMEC Registry): patterns of clinical and immunological expression in 180 cases. J Intern Med 2005;257:549-57.

8. Olivieri I, Palazzi C, Padula A. Hepatitis $C$ virus and arthritis. Rheum Dis Clin North Am 2003;29:111-22.

9. Zuckerman E, Keren D, Rozenbaum M. Hepatitis $C$ virus related arthritis: characteristics and response to therapy with interferon alpha. Clin Exp Rheumatol 2000;18: 579-84.

10. Bizzaro N. Antibodies to citrullinated peptides: a significant step forward in the early diagnosis of rheumatoid arthritis. Clin Chem Lab Med 2007;45:150-7.

11. Girbal-Neuhauser E, Durieux J, Arnaud M, Dalbon P, Sebbag M, Vincent C. The epitopes targeted by the rheumatoid arthritis-associated antifilaggrin autoantibodies are posttranslationally generated on various sites of (pro)filaggrin by deimination of arginine residues. J Immunol 1999;162:585-94.

12. Nishimura K, Sugiyama D, Kogata Y, Tsuji G, Nakazawa $T$, Kawano S, et al. Meta-analysis: diagnostic accuracy of anti-cyclic citrullinated peptide antibody and rheumatoid 
factor for rheumatoid arthritis. Ann Intern Med 2007; 146:797-808.

13. Rieu V, Cohen $\mathrm{P}$, André MH, Mouthon L, Godmer P, Jarrousse $B$, et al. Characteristics and outcome of 49 patients with symptomatic cryoglobulinaemia. Rheumatology 2002;41:290-300.

14. Bedossa P, Poynard T. An algorithm for the grading of activity in chronic hepatitis $\mathrm{C}$. The METAVIR Cooperative Study Group. Hepatology 1996;24:289-93.

15. Bas S, Genevay S, Meyer O, Gabay C. Anti-cyclic citrullinated peptide antibodies, IgM and IgA rheumatoid factors in the diagnosis and prognosis of rheumatoid arthritis. Rheumatology 2003;42:677-80.

16. Van Boekel M, Vossenaar $E$, van den Hoogen F, van Venrooij $W$. Autoantibody systems in rheumatoid arthritis: specificity, sensitivity and diagnostic value. Arthritis Res 2002;4:87-93.

17. Sène $D$, Ghillani-Dalbin $P$, Limal $N$, Thibault $V$, van Boekel T, Piette JC, et al. Anti-cyclic citrullinated peptide antibodies in hepatitis $C$ virus associated rheumatological manifestations and Sjögren's syndrome. Ann Rheum Dis 2006;65:394-7.

18. Wener M, Hutchinson K, Morishima C, Gretch D. Absence of antibodies to cyclic citrullinated peptide in sera of patients with hepatitis $C$ virus infection and cryoglobulinemia. Arthritis Rheum 2004;50:2305-8.

19. Liu F, Chao Y, Hou T, Chen H, Shyu R, Hsieh T, et al. Usefulness of anti-CCP antibodies in patients with hepatitis $C$ virus infection with or without arthritis, rheumatoid factor, or cryoglobulinemia. Clin Rheumatol 2008;27:463-7.

20. Girelli F, Foschi F, Bedeschi E. Is anti-cyclic citrullinated peptide a useful laboratory test for the diagnosis of rheumatoid arthritis? Allerg Immunol 2004;36:127-30.

21. Nguyen M, Keeffe E. Chronic hepatitis C: genotypes 4 to 9. Clin Liver Dis 2005;9:411-26.

22. Makrygiannakis D, Klint E, Lundberg I, Löfberg R, Ulfgren A, Klareskog $L$, et al. Citrullination is an inflammation-dependent process. Ann Rheum Dis 2006;65: 1219-22.
23. Vannini A, Cheung K, Fusconi M, Stammen-Vogelzangs J, Drenth J, Dall'Aglio A, et al. Anti-cyclic citrullinated peptide positivity in non-rheumatoid arthritis disease samples: citrulline-dependent or not? Ann Rheum Dis 2007;66:511-6.

24. Takasaki Y, Yamanaka K, Takasaki C, Matsushita M, Yamada H, Nawata M, et al. Anticyclic citrullinated peptide antibodies in patients with mixed connective tissue disease. Mod Rheumatol 2004;14:367-75.

25. Gottenberg J, Mignot S, Nicaise-Rolland P, Cohen-Solal $\mathrm{J}$, Aucouturier F, Goetz J, et al. Prevalence of anti-cyclic citrullinated peptide and anti-keratin antibodies in patients with primary Sjögren's syndrome. Ann Rheum Dis 2005;64:114-7.

26. Vander Cruyssen B, Hoffman I, Zmierczak H, Van den Berghe M, Kruithof E, De Rycke L, et al. Anti-citrullinated peptide antibodies may occur in patients with psoriatic arthritis. Ann Rheum Dis 2005;64:1145-9.

27. Alenius G, Berglin E, Rantapää Dahlqvist S. Antibodies against cyclic citrullinated peptide (CCP) in psoriatic patients with or without joint inflammation. Ann Rheum Dis 2006;65:398-400.

28. Fusconi M, Vannini A, Dall'Aglio A, Pappas G, Cassani F, Ballardini G, et al. Anti-cyclic citrullinated peptide antibodies in type 1 autoimmune hepatitis. Aliment Pharmacol Ther 2005;22:951-5.

29. Bianchi F, Muratori P, Granito A, Pappas G, Ferri S, Muratori L. Hepatitis C and autoreactivity. Dig Liver Dis 2007;39:S22-4.

30. Lopez-Hoyos M, Marquina R, Tamayo E, Gonzalez-Rojas J, Izui S, Merino J. Defects in the regulation of B cell apoptosis are required for the production of citrullinated peptide auto-antibodies in mice. Arthritis Rheum 2003; 48:2353-61.

31. Montano-Loza A, Czaja A, Carpenter H, Piette A, Murphy $D$, Shums $Z$, et al. Frequency and significance of antibodies to cyclic citrullinated peptide in type 1 autoimmune hepatitis. Autoimmunity 2006;39:341-8.

32. Vossenaar E, Robinson W. Citrullination and autoimmune disease: 8th Bertine Koperberg meeting. Ann Rheum Dis 2005;64:1513-5. 